\title{
Research on Cultivating Competition in Urban Tourism Market
}

\author{
Bin Shi \\ Xi'an Siyuan University
}

\begin{abstract}
Keywords: Tourism competitiveness; Industrial competitiveness; Competitiveness evaluation; Urban tourism
\end{abstract}

\begin{abstract}
Competitiveness theory has been developed rapidly and widely used because it adapts to the current economic globalization, systematization, complexity, and the trend of digitalization, informationization and modeling of economic research. Tourism is a new industry in China, in recent years has been the common attention of domestic cities, tourism investment has grown rapidly, the competition between regions is becoming increasingly fierce. Urban tourism, the purpose of this paper is to develop and improve the industrial competitiveness of industrial tourism in the field of urban tourism theory system, exploration, from the perspective of urban space competition and cooperation, put forward to enhance the competitiveness of urban tourism industry reasonable.
\end{abstract}

\section{Introduction}

In the global economic activities, the tourism industry is one of the fastest growing industries, after years of rapid development, tourism has become a new growth point of the national economy. However, from the perspective of industrial organization analysis, we can see that the urban tourism industry concentration is low, the tourism industry structure is unreasonable, and the product structure does not match the supply structure and the market demand structure. It is not synchronized, "Small, scattered, weak, poor" situation, many enterprises in order to compete for market share, had to carry out vicious price competition, resulting in the industry as a whole in the total income increases, while profit margins continue to decline, or even negative profit margins The Therefore, look to the future, the international tourism market competition will become increasingly fierce, the city tourism industry to enhance their status, will face many obstacles and difficulties. In order to realize the strategic goal of transcending the tourism power of the world from the Asian tourism power, we must combine the theory and practice to evaluate the current situation of the competitiveness of the urban tourism industry objectively and strive to find a reasonable way of competition and make use of the abundant urban tourism resources and Huge industry market space to further promote the sustainable development of tourism.

Due to the characteristics of spatial displacement, the development of tourism industry is bound to be related to certain spatial structure, which shows some characteristics of industrial space. These characteristics determine the inevitability and characteristics of tourism competitiveness.

In order to improve the competitiveness of the tourism industry, many scholars have also started this research, Crouch GI[1] and others from the social value, the full range of the relationship between tourism and competition, Mihalič T[2] And so on from the perspective of the environment, the study of environmental impact on tourism competition. Hanafiah M H[3] elaborated his own influencing factors on the core competitiveness of tourism in his writings. With the deepening of tourism research, more and more research teams have elaborated their views on enhancing the competitiveness of tourism[4-10].

This paper puts forward the analysis paradigm of the competitiveness of urban tourism industry with the results of modern management, urban economics and tourism and other related disciplines, and discusses the factors that determine the competitive advantage of urban tourism industry as the factorization and the specialization of urban tourism development Level, the demand situation and the level of urban tourism development and the level of tourism enterprise development group. And from the perspective of competitiveness of urban tourism industry system, in the tourism industry competitiveness index system on the basis of research progress, to build a more complete urban 
tourism industry competitiveness evaluation model and index system.

\section{Competitiveness}

Competitiveness is the ability of each subject in the competition to obtain the resources it wants to obtain, which is manifested as the realization of the main development goal and the overall strength of the growth, and through the subject of the strategic behavior can be achieved. The above definition contains several layers of meaning. First, the competitiveness is a point, is the target of the main behavior. Second, the strength of competitiveness, and ultimately embodies the main objectives of the realization and strength of growth, and depends on the main resource allocation, production and other economic decision-making and action. Third, the competitiveness is different from the comprehensive strength, the former is facing the future, the latter is the historical result, the former is the relative comparison concept, the latter is the absolute sense of the concept of stock, which is one of the former factors.

Industrial competitiveness refers to the ability of different regional economic entities to develop resources in competitive industries in an industry, depending on the industrial base of the regional subject and the formulation of industrial policies, the regulation of industrial structure and other subjective economic behavior, reflected in the regional industry as a whole to improve the efficiency And the rationalization of the overall industrial resource allocation in the region.

Urban competitiveness refers to the social and economic structure, values, culture, institutions and policies and other factors combined to create and maintain a comprehensive development of a city for its own in the region to optimize the allocation of resources. It is to obtain their own economic sustained high growth, promote the region, the state and even the world to create more social wealth capacity. The strong performance of urban competitiveness compared with other cities in the region can attract more people, logistics and radiation greater market space.

The competitiveness of the urban tourism industry refers to the ability of the tourism enterprises to sell their products in the tourism market and reflect the sustainable development and development ability of the tourism industry under the combined effect of the tourism industry itself and the tourism environment in the urban area.

\section{Analysis of Industrial Competitiveness}

Industrial competitiveness is reflected in the market competition in the comparative relationship, so the competitiveness of the industry first manifested in the market, such as product prices, cost, quality, service, brand and differentiation and other aspects of the competitor has the ability to differentiate. This direct performance in the market competition, known as the industry's direct competitiveness. The direct performance of industrial competitiveness mainly includes price and cost, quality, brand, product structure, service, differentiation and so on.

Among the above six factors, this paper argues that differentiation is the most important factor. The economic significance of differentiation is that manufacturing is scarce. It is an aspect of manufacturing a product in a market structure where supply or demand is balanced or oversupply. The process of product management is different from the scarcity of competitors, that is, "local demand", so that their products have a competitive advantage, as well as the excess value of innovation. Competitive advantages of enterprises have a strong ability to differentiate, or that differentiation is a certain business in the competition come to the fore. To achieve the difference between the different tools of product differentiation, service differentiation, personnel differentiation, channel differentiation and image differentiation. The Differentiation is shown in Table 1. 
Table 1 Variance of difference

\begin{tabular}{|c|c|c|c|c|}
\hline product & Service & personnel & channel & Image \\
\hline features & easy ordering & ability & cover area & Logo \\
\hline $\begin{array}{c}\text { performance } \\
\text { consistency }\end{array}$ & delivery & modest & specialization & $\begin{array}{c}\text { text and } \\
\text { multimedia }\end{array}$ \\
\hline durability & installation & honest & performance & atmosphere \\
\hline reliability & $\begin{array}{c}\text { customer } \\
\text { training }\end{array}$ & reliable & & event \\
\hline maintainability & $\begin{array}{c}\text { customer } \\
\text { service }\end{array}$ & responsibility & & \\
\hline style & service & communication & & \\
\hline design & $\begin{array}{c}\text { diverse } \\
\text { services }\end{array}$ & & & \\
\hline
\end{tabular}

\section{Paradigm of Competitiveness of Urban Tourism Industry}

The paradigm of the study of urban tourism industry competitiveness is the basic intention of researchers in this field to describe and analyze the conceptual selection of this topic, the selection of specific phenomena and problems for observation and investigation, The strategy used in the process.

\section{Conclusion}

Tourism industry as a comprehensive industrial sector, its scope of management should be from the planned economy under the conditions of the system of management into a market economy under the conditions of social block management, that is what we call the whole industry management. Tourism management departments must overcome these difficulties, resolutely implement a full range of tourism industry management. We must deal with the following aspects of the relationship: Relationship between Tourism Management and Integrated Management; The relationship between tourism management department and relevant management department; Provincial Tourism Bureau and the provincial capital city tourism bureau relations

\section{References}

[1] Crouch G I, Ritchie J R B. Tourism, competitiveness, and societal prosperity[J]. Journal of business research, 1999, 44(3): 137-152.

[2] Mihalič T. Environmental management of a tourist destination: A factor of tourism competitiveness[J]. Tourism management, 2000, 21(1): 65-78.

[3] Hanafiah M H, Hemdi M A, Ahmad I. The Influence of Tourism Core Resources on Travel and the Tourism Competitiveness Index and Tourism Performance[M]//Balancing Development and Sustainability in Tourism Destinations. Springer Singapore, 2017: 377-384.

[4] Kubickova M, Croes R, Rivera M. Human agency shaping tourism competitiveness and quality of life in developing economies[J]. Tourism Management Perspectives, 2017, 22: 120-131.

[5] Perles-Ribes J F, Ramón-Rodríguez A B, Rubia-Serrano A, et al. Economic crisis and tourism competitiveness in Spain: permanent effects or transitory shocks?[J]. Current Issues in Tourism, 2016, 19(12): 1210-1234.

[6] Dias J G. Environmental sustainability measurement in the Travel \& Tourism Competitiveness Index: An empirical analysis of its reliability[J]. Ecological Indicators, 2017, 73: 589-596.

[7] Chang L. Study On The Influence Of Regional Tourism Planning On Regional Tourism Competitiveness_- Taking Ecological And Cultural Tourism Zone Of Western Hubei As An Example[C]//Jiangsu Commercial Forum. 2016, 3: 015.

[8] Nasr N E S. Raising competitiveness for the Travel and Tourism Industry (the Case of Egypt)[J]. International Journal of Heritage, Tourism, and Hospitality, 2017, 10(2/2). 
[9] Katou A A, Katsouli E F. Empirical Evidence on Convergence of Travel and Tourism Competitiveness and Global Competitiveness Across the BRIC Countries[J]. Opportunities and Challenges for Tourism and Hospitality in the BRIC Nations, 2016, 198(143.5): 1,252.1-1,357.4.

[10]Katou A A, Katsouli E F. Empirical Evidence on Convergence of Travel and Tourism Competitiveness and Global Competitiveness Across the BRIC Countries[J]. Opportunities and Challenges for Tourism and Hospitality in the BRIC Nations, 2016, 198(143.5): 1,252.1-1,357.4. 